\title{
siRNA-mediated silencing of integrin $\beta 3$ expression inhibits the metastatic potential of B16 melanoma cells
}

\author{
ANNA NASULEWICZ-GOLDEMAN, BARBARA USZCZYŃSKA, \\ KATARZYNA SZCZAURSKA-NOWAK and JOANNA WIETRZYK
}

\begin{abstract}
Department of Experimental Oncology, Institute of Immunology and Experimental Therapy, Polish Academy of Sciences, 12 R. Weigl Street, 53-114 Wroclaw, Poland
\end{abstract}

Received May 18, 2012; Accepted July 20, 2012

DOI: $10.3892 / o r .2012 .1963$

\begin{abstract}
Integrins comprise a large family of $\alpha \beta$ heterodimeric cell-surface receptors that mediate diverse processes involved in cell-cell and cell-matrix interactions such as cellular adhesion and migration, cell survival and differentiation. It is now well documented that integrins play a crucial role in cancer metastasis and angiogenesis. The $\beta 3$ integrins appear to have an important stimulatory role in tumour progression and metastasis and, thus, have been often proposed as potential targets for cancer diagnosis and therapy. In this study, we evaluated the in vitro and in vivo properties of B16 mouse melanoma cells with low expression of integrin $\beta 3$. Proliferation rate, adhesive properties and the ability to migrate and metastasize were studied. Over $90 \%$ inhibition of integrin $\beta 3$ expression was achieved as a result of the transfection with siRNA. No changes in the proliferation rate were observed in siRNA-transfected B16 cells; however, they showed impaired ability to bind to fibronectin. Moreover, inhibition of integrin $\beta 3$ expression caused almost complete impairment of the ability of B16 cells to migrate through matrigel and metastasize. The mean number of lung metastatic colonies in mice inoculated intravenously with B16 expressing low levels of integrin $\beta 3$ was decreased to 14 colonies compared to 101 in the control group. These results provide evidence for a direct role of integrin $\beta 3$ in the adhesion, migration and metastasis processes of mouse melanoma cells and point to the potential therapeutic advantages of siRNAs.
\end{abstract}

\section{Introduction}

Integrins comprise a large family of $\alpha \beta$ heterodimeric cellsurface receptors that are expressed in a wide variety of

Correspondence to: Dr Anna Nasulewicz-Goldeman, Department of Experimental Oncology, Institute of Immunology and Experimental Therapy, Polish Academy of Sciences, 12, R. Weigl Street, 53-114 Wroclaw, Poland

E-mail: nasulewicz@iitd.pan.wroc.pl

Key words: integrins, metastasis, mouse melanoma, RNA interference, siRNA cells. They mediate diverse processes and are involved in cell-cell and cell-matrix interactions such as cell adhesion and migration, cell survival and differentiation. It is now well documented that integrins play a crucial role in cancer progression, metastasis and neoangiogenesis.

There are two members of integrin $\beta 3$ family: $\alpha v \beta 3$ and $\alpha \operatorname{IIb} \beta 3 . \alpha v \beta 3$ integrin is strongly expressed on the surface of the smooth muscle cells, endothelial cells, monocytes and platelets. Dysregulation of $\beta 3$ integrin expression is associated with the pathogenesis of several diseases, including cancer. Many invasive tumour cells, including melanoma show an overexpression of this integrin. There are also reports indicating the correlation between $\alpha v \beta 3$ integrin expression and the stage of tumour progression (1-5). $\beta 3$ integrins are also strongly involved in tumour-induced angiogenesis and have been described as pro-angiogenic factors $(6,7)$. The role of $\alpha v \beta 3$ integrin in tumour angiogenesis is related not to its expression by neoplastic cells, but rather to its expression by host endothelial cells (8). Moreover, it was proven that antagonists of $\alpha v \beta 3$ inhibit angiogenic processes, including endothelial cell adhesion and migration, whereas factors, which increase $\alpha \mathrm{v} \beta 3$ integrin expression, induce angiogenesis $(9,10)$.

$\alpha \operatorname{IIb} \beta 3$ integrin expression is limited mainly to platelets, megakaryocytes, human blood monocytes, granulocytes, and large granular lymphocytes (11). However, there is increasing evidence that $\alpha \operatorname{IIb} \beta 3$ integrin is also present in the tumour cells (3). Its expression is connected with tumour thickness, invasion abilities and metastatic potential of human and mouse melanomas $(3,8)$. Various studies showed that $\alpha \operatorname{IIb} \beta 3$ is constitutively expressed at a high-affinity state and is highly involved in tumour cell adhesion and invasion (12).

$\alpha \operatorname{Ilb} \beta 3$ integrin is also involved in tumour-induced platelet aggregation, which has been described as an important step of metastasis pathway. Tumour cells during migration in blood vessels can form complexes with platelets. This process, resulting from direct binding of platelets to tumour cells, is essential for metastasis $(8,13)$.

The $\beta 3$ integrins appear to have an important stimulatory role in tumour progression and metastasis and that is why $\beta 3$ integrins have often been proposed as potential targets for cancer diagnostic and therapeutic approaches. Application of anti-integrin antibodies and RGD (Arg-Gly-Asp) related peptides have revealed promising effects in anticancer therapy 
(14-17). One of the most interesting integrin-targeting tools are short interfering RNAs (siRNAs).

In this study, the in vitro and in vivo properties of B16 mouse melanoma cells with lower expression of integrin $\beta 3$ were evaluated. Proliferation rate, adhesive properties and the ability to migrate and metastasize were studied. In order to achieve cells with low expression of integrin $\beta 3$, transfection with siRNA was employed. B16 cells that fail to express integrin $\beta 3$ show impaired motility and ability to bind to extracellular matrix (ECM) proteins, and are unable to colonize lungs. These results provide supplementary data for a direct role of integrin $\beta 3$ in the adhesion, migration and metastasis processes of mouse melanoma cells and prove that the silencing of integrin expression can be efficiently and selectively obtained using siRNAs.

\section{Materials and methods}

Cell culture. The mouse melanoma B16 cells were obtained from the American Type Culture Collection (Rockville, MD, USA) and maintained in the Cell Culture Collection of the Institute of Immunology and Experimental Therapy Polish Academy of Sciences (IIET, PASc), Wroclaw, Poland. Cells were cultured in RPMI medium supplemented with $4 \mathrm{mM}$ L-glutamine, $4.5 \mathrm{~g} / 1$ glucose, $1.5 \mathrm{~g} / 1 \mathrm{NaHCO}_{3}$ (both from Sigma-Aldrich Chemie GmbH, Steinheim, Germany), $100 \mathrm{U} / \mathrm{ml}$ penicillin, $100 \mu \mathrm{g} / \mathrm{ml}$ streptomycin (both from Polfa Tarchomin S.A., Warsaw, Poland) and 10\% FBS (Sigma-Aldrich Chemie $\mathrm{GmbH})$.

siRNA. The siRNAs (sense and antisense strands) were purchased from Qiagen (Qiagen Inc., Valencia, USA) and were diluted according to manufacturer's instructions and then stored at $-20^{\circ} \mathrm{C}$. The following sequences were tested for their effectiveness in silencing integrin $\beta 3$ expression: Sequence M1: sense r(GCCGUGAAUUGUACCUACA)dTdT, antisense r(UGUA GGUACAAUUCACGGC)dGdT; Sequence M2: sense r(CGG UGAGCUUUAGUAUCGA)dTdT, antisense r(UCGAUACUA AAGCUCACCG)dTdG. As a control, a negative siRNA, with no homology to mRNA databases was used (Silencer ${ }^{\circledR}$ Negative Control \#1 siRNA, Ambion).

In vitro transfections were performed using HiPerFect reagent (Qiagen Inc.) as recommended by the manufacturer. Cells were plated on a 24 -well plate in $0.5 \mathrm{ml}$ of medium RPMI-O-MEM without antibiotics and FBS $\left(4 \times 10^{4}\right.$ cells per well). Shortly after plating, cells were transfected with $100 \mu \mathrm{l}$ of the transfection mixture containing 5 or $25 \mathrm{nM}$ of siRNA. Cells were washed $6 \mathrm{~h}$ after transfection and the procedure was repeated $48 \mathrm{~h}$ later.

Integrin quantification. The expression of integrin $\beta 3$ (CD61) (Becton Dickinson, San Jose, USA) was determined by flow cytometry. B16 cells $\left(1 \times 10^{5}\right)$ were mixed with an appropriate volume of $\mathrm{McAb}$ solution (pre-chilled to $4^{\circ} \mathrm{C}$ ). Cells were incubated for $30 \mathrm{~min}$ on an ice bath, and subsequently washed twice with PBS (supplemented with $2 \%$ fetal bovine serum). Cell surface fluorescence was measured using a FACS Calibur flow cytometer (Becton Dickinson). Damaged cells were labeled with propidium iodide solution to each test tube just before data acquisition. Data for damaged cells were not analyzed. Data analysis was performed using WinMDI 2.8 software.

Semi-quantitative PCR. Total RNA extraction, DNA digestion and cDNA synthesis was performed with RNAlater RNA Stabilization Reagent ${ }^{\mathrm{TM}}$ (Qiagen Inc.) according to the manufacture's procedure. PCR reaction was performed using the following primers: integrin $\beta 3$ : forward 5'TCAGATGCGCA AGCTTACTAGC3', reverse 5'TCAGCACGTGTTTGTAGC CAA3'; GAPDH: forward: 5'ATGACATCAAGAAGGTG GTG3', reverse: 5'CATACCAGGAAATGAGCTTG3'. PCR cycling conditions were $94^{\circ} \mathrm{C}$ for $30 \mathrm{sec}, 55^{\circ} \mathrm{C}$ for $30 \mathrm{sec}$, and $72^{\circ} \mathrm{C}$ for $1 \mathrm{~min}, 35$ cycles for integrin $\beta 3$ expression and 25 cycles for GAPDH. PCR products were dissolved in $1.7 \%$ agarose gel with ethidium bromide.

Antiproliferative assays. Cells were plated in 96-well plates (Sarstedt, Inc. Newton, NC, USA) at the density of $8 \times 10^{3}$ cells per well in $100 \mu \mathrm{l}$ of culture medium without FBS and antibiotics. After $24 \mathrm{~h}$ of incubation at standard conditions $\left(37^{\circ} \mathrm{C}\right.$ in humid atmosphere with $5 \% \mathrm{CO}_{2}$ ), cells were treated with siRNA suspended in $100 \mu \mathrm{l}$ of medium FBS and antibioticsfree. The cytotoxic assays were performed after 24,48 and $72 \mathrm{~h}$ exposure of the cultured cells to varying concentrations siRNA, e.g. 1, 5 and $25 \mathrm{nM}$. The amount of HiPerFect was stable $(3 \mu \mathrm{l}$ per well). The SRB method was used as described by Skehan and coworkers (18). The optical densities of the samples were measured on a Multiskan RC photometer (Labsystems, Helsinki, Finland) at $\lambda=540 \mathrm{~nm}$.

Adhesion assay. Flat-bottomed, 96-well plates were coated with fibrinogen $\left(10 \mu \mathrm{g} / \mathrm{ml}\right.$ suspended in $7.5 \% \mathrm{NaHCO}_{3}$, Merck, Darmstadt, Germany) and blocked with $1 \%$ BSA (SigmaAldrich Chemie $\mathrm{GmbH})$ in TSM buffer $(20 \mathrm{mM}$ Tris- $\mathrm{HCl}$ $\mathrm{pH}$ 8.0, $150 \mathrm{nM} \mathrm{NaCl}, 1 \mathrm{mM} \mathrm{CaCl} 2,2 \mathrm{mM} \mathrm{MgCl} 2$ ). Cells were suspended in $0.5 \%$ solution of BSA, added into plates in the amount of $2.5 \times 10^{4}$ and incubated for $1 \mathrm{~h}$ at $37^{\circ} \mathrm{C}$. Unbound cells were washed out twice with TSM buffer and dyed with $0.2 \%$ solution of crystalline violet in methanol. After $30 \mathrm{~min}$ of incubation at $4^{\circ} \mathrm{C}$, cells were washed with $\mathrm{PBS}^{-\mathrm{Ca} 2+\mathrm{Mg} 2+}$, dried and suspended in $20 \%$ methanol. The absorbance was measured at $\lambda=570 \mathrm{~nm}$ in a computer-interfaced, 96-well microtiter plate reader Multiskan RC photometer.

\section{Migration assay}

Migration chamber preparation. Fibronectin assay: $8-\mu \mathrm{m}$ insert membranes (Falcon BD Biosciences, USA) were sterilely covered with fibronectin $(100 \mu \mathrm{g} / \mathrm{ml}$, Falcon BD Biosciences). Both sides of the membrane were covered with $20 \mu \mathrm{l}$ of the fibronectin suspension and incubated for $30 \mathrm{~min}$ at $37^{\circ} \mathrm{C}$. Fibronectin was removed and the inserts were washed three times with sterile water. Subsequently, both sides of the membrane were immersed in a $0.1 \%$ albumin solution and incubated for $15 \mathrm{~min}$. The inserts were washed three times with sterile water and dried. The prepared inserts were not stored, but used immediately after preparation.

Migration assay. The siRNA M2-transfected, negative siRNA-transfected and non-treated B16 cells were suspended in DMEM with no FBS, and applied to the upper section of the migration chamber, with $2.9 \times 10^{5}$ cells/insert. Culture medium 


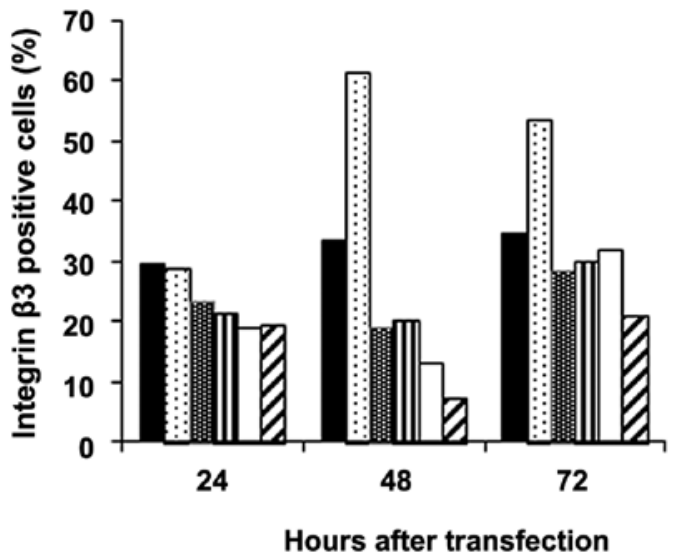

\begin{tabular}{|lll|}
\hline aControl & GHiPerFect & aM1 $5 \mathrm{~nm}$ \\
mM2 $5 \mathrm{~nm}$ & aM1 $25 \mathrm{~nm}$ & $\square \mathrm{M} 225 \mathrm{~nm}$ \\
\hline
\end{tabular}

Figure 1. Time-course of siRNA-mediated inhibition of integrin $\beta 3$ expression on B16 mouse melanoma cells. Cells were transfected with two different siRNA sequences (M1 and M2) at two concentrations and the protein expression was measured by FACS analysis. Non-transfected cells and cells treated only with transfection reagent served as controls.

supplemented with $10 \%$ FBS applied to the lower section served as chemoattractant.

The migration was carried out at $37^{\circ} \mathrm{C}$ with $5 \% \mathrm{CO}_{2}$. The time of migration was initially optimised and for $\mathrm{B} 16$ cells was $2 \mathrm{~h}$. Thereafter (following the manufacturer's instructions), the cells from the upper side of the membrane were removed with a cotton swab. The cells on the bottom side of the membrane were fixed and stained with a Diff-Quick set (Medion Diagnostics, Düdingen, Switzerland) and counted by light microscopy. The number of cells per membrane was determined, accumulated into groups, and the average was presented.

Metastasis assay. Eight- to twelve-week-old C57BL/6/IiW female mice were purchased from Maria Skłodowska-Curie Memorial Cancer Center and Institute of Oncology, Warsaw (Poland) and kept under specific pathogen-free (SPF) conditions. All experiments were performed under standard laboratory conditions according to Interdisciplinary Principles and Guidelines for the Use of Animals in Research, Marketing and Education issued by the New York Academy of Science Ad Hoc Committee on Animal Research and were approved by the 1st Local Committee for Experiments with the Use of Laboratory Animals, Wroclaw, Poland.

Mice were inoculated intravenously (i.v.) with $3 \times 10^{5} \mathrm{~B} 16$ cells (collected from in vitro culture) in $0.2 \mathrm{ml}$ of Hank's medium into the lateral tail vein. Mice were sacrificed by cervical dislocation (21 days after cells inoculation). Lungs were excited and weighed immediately, and lung metastatic foci were counted.

\section{Results}

Inhibition of integrin $\beta 3$ synthesis by RNA interference in vitro. B16 cells were transfected with 5 or $25 \mathrm{nM}$ of M1 and M2 siRNAs. The expression of integrin $\beta 3$ was measured by cytofluorometry after 24,48 and $72 \mathrm{~h}$ after transfection. Both siRNA sequences led to the reduction of integrin $\beta 3$

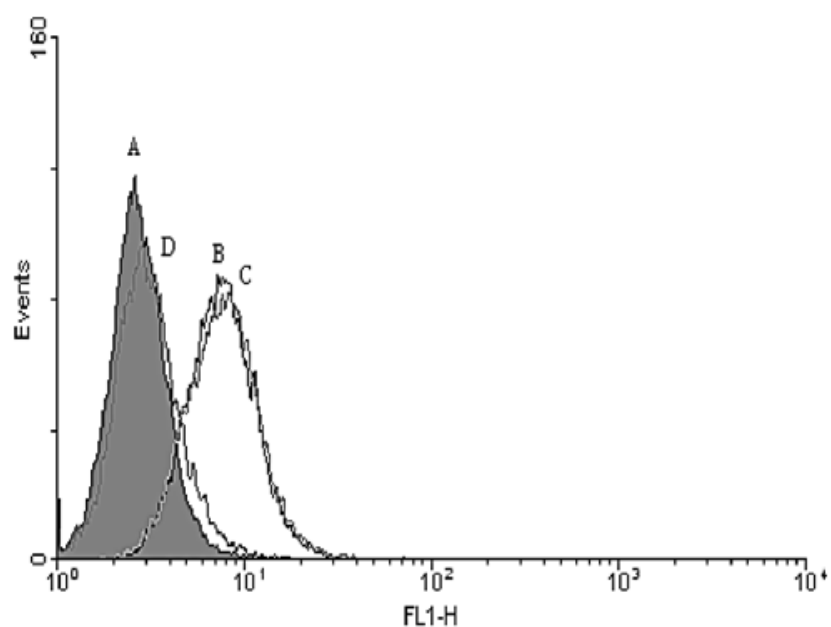

Figure 2. siRNA-mediated inhibition of integrin $\beta 3$ expression on B16 melanoma cells. Non-transfected cells incubated with PBS (A) and McAb (B) served as controls. Cells were transfected with a negative, 'blind' siRNA (C) and siRNA against integrin $\beta 3$ (D). The experiment was repeated 14 times and the histogram shows representative data.

expression as compared to control, non-transfected cells; however, the sequence M2 appeared to be more potent. In both cases, the silencing effect increased with siRNA concentration. However, we also showed that the most effective concentration of siRNA was $25 \mathrm{nM}$ and further increase in siRNA amount did not enhance the effect (data not shown). Moreover, our experiments confirmed that siRNA-mediated silencing of integrin $\beta 3$ expression is transitory, with a highest inhibition of protein expression after $48 \mathrm{~h}$ after transfection. We observed almost $80 \%$ reduction of integrin $\beta 3$ expression on B16 cells $48 \mathrm{~h}$ after transfection with M2 siRNA compared to untreated cells (Fig. 1).

None of the tested sequences showed cytotoxicity. The inhibition of B16 cells proliferation reached only $5 \%, 24 \mathrm{~h}$ after transfection as compared to the control, non-transfected cells, irrespective of siRNA sequence and concentration applied. B16 cells treated with siRNAs achieved a control proliferation rate $72 \mathrm{~h}$ after transfection.

Taking the above-mentioned results into account, we chose M2 sequence for further studies. Comparing the efficacy of integrin $\beta 3$ silencing by a single and a double transfection, we found that it is possible to obtain a significant increase in the inhibition of integrin $\beta 3$ expression due to a transfection repeated after additional $48 \mathrm{~h}$. In that case, the inhibition of integrin $\beta 3$ expression on B16 cells could reach even $98 \%$ (mean inhibition was $87 \pm 8 \%$, which corresponded to $48 \pm 11 \%$ drop in the mean fluorescence canal values). Cells restored integrin $\beta 3$ expression after $96 \mathrm{~h}$ after the first transfection. For negative siRNA, with no homology to any known mRNA, we showed a slight (5\%) and insignificant increase in the integrin $\beta 3$ expression. The representative histogram of transfected B16 cells is shown in Fig. 2.

These changes were confirmed on mRNA level. Semiquantitative PCR revealed a marked decrease in the expression of mRNA for integrin $\beta 3$ as a result of the siRNA transfection. No significant differences were observed in the expression of integrin $\beta 3$ mRNA between control, untreated cells and cells transfected with negative siRNA (Fig. 3). 


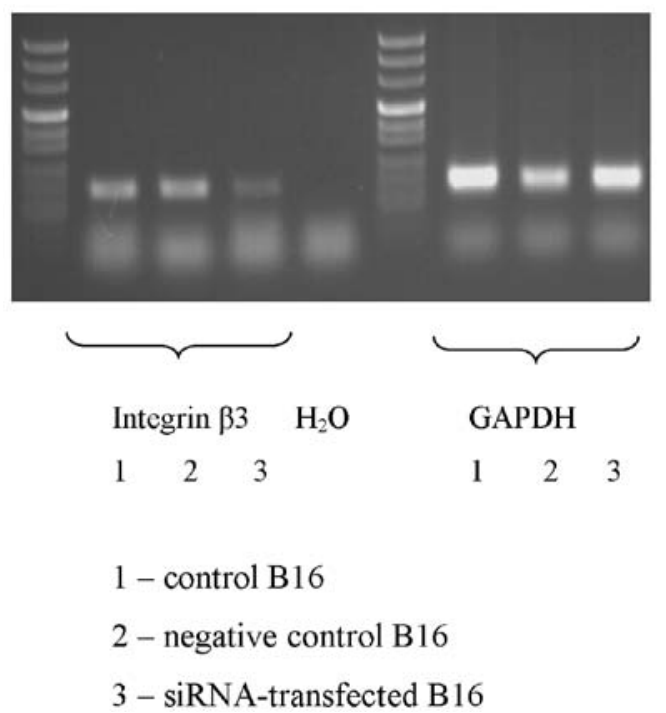

Figure 3. Changes in the expression of mRNA for integrin $\beta 3$ in B16 cells transfected with siRNA for integrin $\beta 3$ (1). Cells were transfected twice with $25 \mathrm{nM}$ of siRNA. Untreated or transfected with negative siRNA B16 cells served as controls. Products of semi-quantitative PCR were dissolved in $1.7 \%$ agarose gel with ethidium bromide.

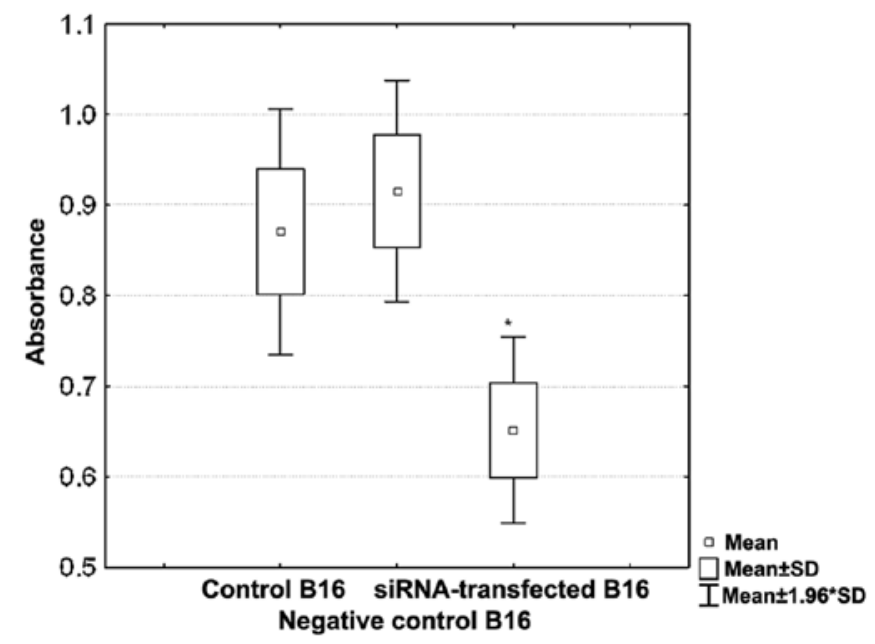

Figure 4. Inhibition of the interactions between B16 melanoma cells and fibrinogen by RNA interference. Cells were transfected twice with $25 \mathrm{nM}$ of siRNA. The experiment was repeated twice and the histogram shows representative data. Values are means after subtraction of the absorbance of BSA and fibrinogen-coated wells \pm SD. ${ }^{*}$ p $<0.01$ assessed with Kruskal-Wallis ANOVA.

Inhibition of cell adhesion to matrix proteins by RNA interference in vitro. To estimate the possible effects of integrin $\beta 3$ silencing on the cell-ECM interactions, we studied adhesive properties of B16 cells on fibrinogen-coated plates. B16 cells were transfected with $25 \mathrm{nM}$ of siRNA and the transfection was repeated after $48 \mathrm{~h}$. The expression of integrin $\beta 3$ was measured by cytofluorometry after additional $24 \mathrm{~h}$. The experiment was repeated twice and in each attempt almost $90 \%$ silencing of integrin $\beta 3$ was obtained. It corresponded to a statistically significant impairment of the adhesion to fibrinogen. siRNAtransfected B16 cells bound to fibrinogen-coated wells were $31 \%$ weaker in comparison to the control, non-transfected cells (Fig. 4).

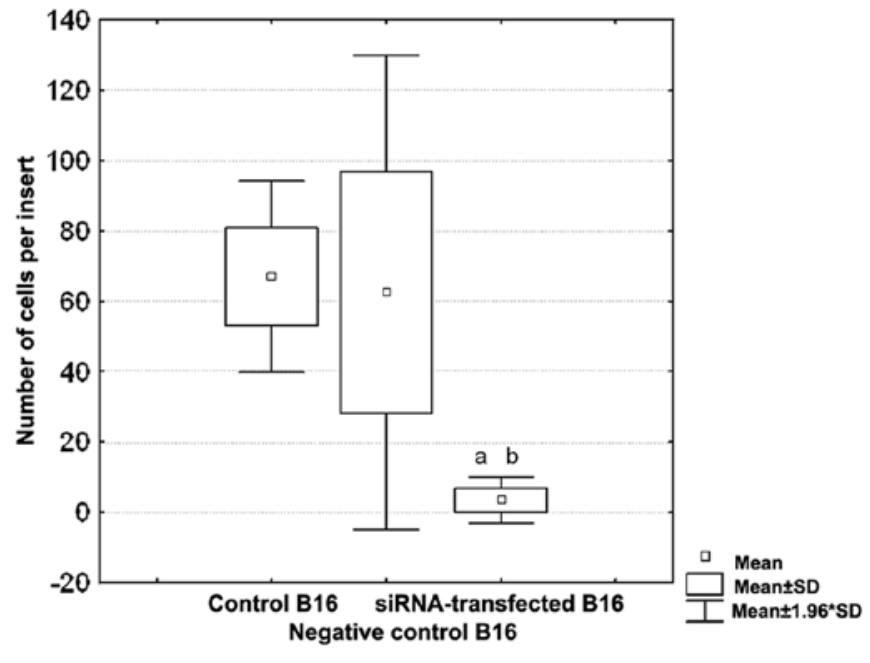

Figure 5. Inhibition of the migration through fibronectin-covered inserts of B16 cells transfected with siRNA against integrin $\beta 3$. Cells were transfected twice with $25 \mathrm{nM}$ of siRNA. Untreated B16 cells served as the control. Cells were applied to the upper section of the migration chamber at the density of $2.9 \times 10^{5}$ cells/insert. The number of cells per membrane was determined, accumulated into groups, and the average is presented. Values are the mean \pm SD. $\mathrm{n}=6-7$, (a) $\mathrm{p}<0.01$ vs. control B16, (b) $\mathrm{p}<0.05$ vs. negative control B16 assessed with Kruskal-Wallis ANOVA.

Inhibition of cell migration by RNA interference in vitro. To verify the influence of integrin $\beta 3$ on the motility of B16 melanoma cells, the migration assay was performed. B16 cells with silenced expression of integrin $\beta 3$ (80\% lower than the control, untreated cells) were applied. Inhibition of integrin $\beta 3$ expression caused almost complete impairment of the ability of B16 cells to migrate through the fibronectin-coated inserts (Fig. 5). Mean number of B16 siRNA-transfected cells detected on the bottom side of the membrane was $4 \pm 3$, whereas this value for the control, untreated cells was $67 \pm 14(p<0.01)$. No influence of the transfection with negative siRNA on the cell motility was observed (63 \pm 34$)$.

Inhibition of metastatic potential by RNA interference. C57/ BL6 mice were inoculated intravenously (i.v.) with B16 cells transfected with anti-integrin $\beta 3$ siRNA, negative siRNA or non-transfected, control ones. A correlation between the level of silencing of integrin $\beta 3$ expression and the inhibition of metastatic potential of B16 cells was observed. In the first experiment, the expression of integrin $\beta 3$ on siRNA-treated cells was inhibited by $55 \%$. At the end of the experiment, the lungs were excised and weighed. The mean lung weight in the control mice was $0.74 \mathrm{~g}$. It was significantly decreased in the group of mice inoculated with B16 cells transfected with siRNA against integrin $\beta 3$ (Fig. 6A). The $42 \%$ drop in the lung weight in these mice corresponded to $55 \%$ decrease in the expression of CD61 in the transfected cells measured by cytofluorymetry prior to the melanoma cells inoculation. However, $83 \%$ silencing of integrin $\beta 3$ expression led to $86 \%$ drop in the number of lung metastatic foci as compared to the control values (Fig. 6B). No significant inhibition of metastatic potential of B16 cells treated with negative siRNA was observed. 

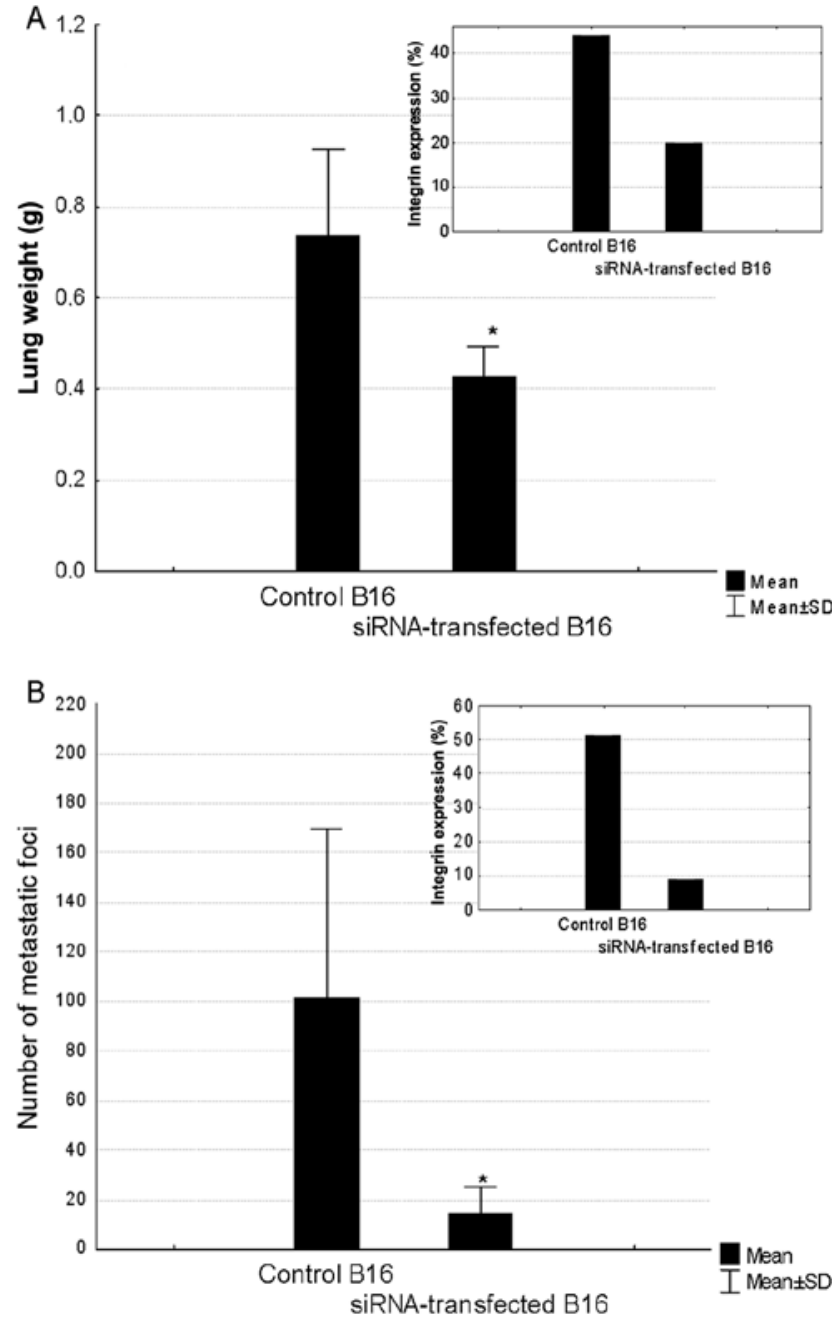

Figure 6. Relationship between integrin expression and metastatic potential of B16 cells. Cells were transfected once (A) or twice (B) with $25 \mathrm{nM}$ of siRNA for integrin $\beta 3$. Mice were inoculated intravenously with $3 \times 10^{5}$ cells. Twenty-one days after inoculation of B16 cells, lungs were excised and weighed immediately, and lung metastatic foci were counted. Values are mean \pm SD. $n=7$ (A) or $\mathrm{n}=8(\mathrm{~B}),{ }^{*} \mathrm{p}<0.01$ assessed with Kruskal-Wallis ANOVA.

\section{Discussion}

Many studies have shown that the expression of integrins alters frequently during malignant transformation. These changes comprise both alterations in the number and identity of integrin receptors on cancer cells (8). Special attention is focused on the role of both $\alpha v \beta 3$ and $\alpha \operatorname{IIb} \beta 3$ in tumour growth, invasion and metastasis. Tumour cells expressing $\alpha v \beta 3$ and/or $\alpha \mathrm{IIb} \beta 3$ display increased survival and growth in vivo (3), and increased metastatic potential (19). Upregulation of integrin expression results in alteration of the ability of malignant cells to interact with the extracellular matrix, and promotes migration as well as facilitates survival outside the tumour microenvironment.

The importance of both $\alpha v \beta 3$ and $\alpha \operatorname{IIb} \beta 3$ has been extensively studied in melanoma. Presence of $\beta 3$ subunit is a characteristic of melanoma, and is strongly associated with the disease progression and poor prognosis $(1-2,20)$.

Integrins have been shown to be potential targets for drug development for therapeutic applications including anticancer treatment (21). Biological methods targeting integrins include monoclonal antibodies $(16,22,23)$, peptides containing RGD or KGD motifs $(24,25)$, RGD analogues (26), and more recently, siRNAs $(27,28)$. RNA interference (RNAi) is a sequencespecific post-transcriptional gene silencing by double-stranded RNA. This mechanism, first discovered by Mello and Fire in Caenorhabditis elegans is present and conserved in a range of organisms (29). Despite the endogenous origin, siRNA can be introduced efficiently into the cells. For over a decade now, siRNAs have been successfully used for targeting and knockdown of sequence-specific mRNAs and has become a key experimental tool for the analysis of gene function. SiRNA have also moved into the clinic; several siRNA-based therapeutic strategies have entered clinical trials (30).

Herein, we report for the first time that siRNA can selectively and efficiently silence the expression of integrin $\beta 3$ subunit in B16 melanoma cells. The effect is manifested $48 \mathrm{~h}$ after transfection and can be significantly enhanced by double transfection (first, shortly after seeding of the cells and second, $48 \mathrm{~h}$ later). Integrin $\beta 3$-silencing does not affect the proliferation rate of $\mathrm{B} 16$ cells.

Clinically, metastatic phenotype of melanoma tumours depends on peculiar adhesive, invasive and migratory properties of tumour cells. This is mostly correlated with the expression of the adhesion receptor integrin $\alpha v \beta 3$ and $\alpha \operatorname{IIb} \beta 3$.

In order to metastasise, tumour cells need to detach from the primary tumour, gain access to blood vessels, survive in blood stream, then attach to vascular endothelial cells, extravasate from blood vessels and finally, colonize distant tissues and organs. These steps are strongly dependent on the cross-talk between tumour and endothelial cells as well as on cell-ECM interactions. Among ECM ligands for $\beta 3$ integrins, fibrinogen, fibronectin and vitronectin are of special importance (31-34). It has been shown that in fibrinogen-deficient mice, a significant reduction in the number of lung metastases formed by B16 melanoma and LLC (Lewis Lung Carcinoma) cells was observed (35). Proteolytic fragments or recombinant peptides containing certain domains of fibronectin can inhibit integrinmediated adhesion, angiogenesis and metastasis in various experimental tumour models (36-39; reviewed in refs. 21,41). In our studies, the transfection of B16 melanoma cells with siRNA for integrin $\beta 3$, resulting in $90 \%$ silencing of protein expression, corresponding to a statistically significant impairment of the adhesion to fibrinogen. siRNA-transfected B16 cells bound to fibrinogen-coated plates were $31 \%$ weaker than the control, integrin-positive cells. These observations probably point toward the involvement of other adhesive proteins in the interactions between B16 melanoma cell and fibrinogen. These may include $\alpha 4 \beta 1$ or $\alpha 5 \beta 1$ integrins $(40,41)$.

In these studies, we also show that siRNA-mediated silencing of integrin $\beta 3$ expression significantly affects the metastatic potential of B16 cells. B16 cells that express lower levels of integrin $\beta 3$ form less metastatic foci in lungs when injected into tail vein in comparison to the control non-transfected cells. This may result from the impairment of several steps which are crucial for the colonization of distant organs, i.e. i) survival in bloodstream, ii) attachment to vascular endothelial cells, iii) basal membrane disintegration, iv) extravasation from vessel lumen, and v) establishment of secondary tumours. Integrin $\beta 3$ expressed on the surface of B16 cells is involved in all these steps. Since the integrin $\beta 3-k n o c k d o w n$ 
is transitory, it seems that the impairment of early steps of this 'metastatic cascade' is crucial for long-term effects observed in our studies. It has been shown that the survival rate of tumour cells in bloodstream may be connected with the interactions between tumour cells and platelets, which, in turn, seem to be fibrinogen related. Recent studies have demonstrated that platelets and fibrinogen facilitate each other in protecting tumour cells from natural killer cytotoxicity (42). It has also been suggested that the formation of platelet-fibrin-tumour cell aggregates may be causally related to endothelial adhesion and metastatic potential (43-45). Since the adhesion to fibrinogen is inhibited in $\beta 3$-deficient cells, this may explain the low metastatic potential of siRNA-transfected B16 cells.

$\beta 3$-silenced cells are probably unable to adhere to vessel walls. It may be suggested that the production and/or activation of matrix metalloproteinases (MMPs) essential for basement membrane disruption is inhibited $(46,47)$. This may clearly affect the migration of B16 cells through the vessel walls. We also show that silencing of $\beta 3$ expression in B16 cells leads to a dramatic loss of migratory properties. This could be explained both by the inhibition of B16 cells-ECM interactions as well as by the abrogation of signal transduction pathways promoting cell motility (48-51).

In summary, our experiments have proved that siRNA transfection is an effective tool for the silencing of integrin $\beta 3$ expression in B16 melanoma cells. The inhibition of integrin $\beta 3$ expression on cell surface is correlated with impaired motility, ability to bind to ECM proteins and significantly lower metastatic potential. Furthermore, our studies suggest that the impairment of early steps of this 'metastatic cascade' is crucial for long-term effects.

\section{References}

1. Albelda SM, Mette SA, Elder DE, Stewart R, Damjanovich L, Herlyn $M$ and Buck CA: Integrin distribution in malignant melanoma: association of the $\beta 3$ subunit with tumor progression. Cancer Res 50: 6757-6764, 1990.

2. Hieken TJ, Farolan M, Ronan SG, Shilkaitis A, Wild L and Das Gupta TK: $\beta 3$ integrin expression in melanoma predicts subsequent metastasis. J Surg Res 63: 169-173, 1996.

3. Trikha M, Timar J, Zacharek A, Nemeth JA, Cai Y, Dome B, Somlai B, Raso E, Ladanyi A and Honn KV: Role for $\beta 3$ integrins in human melanoma growth and survival. Int J Cancer 101: 156-167, 2002.

4. Cooper CR, Chay CH and Pienta KJ: The Role of alpha(v)beta(3) in prostate cancer progression. Neolplasia 4: 191-194, 2002.

5. Rezaeipoor R, Chaney EJ, Oldenburg AL and Boopart S: Expression order of alpha-v and beta-3 integrin subunits in the $\mathrm{N}$-methyl-N-nitrosourea-induced rat mammary tumor model. Cancer Invest 27: 496-503, 2009.

6. Leu SJ, Lam SC and Lau LF: Pro-angiogenic activities of CYR61 (CCN1) mediated through integrins avb3 and a6b1 in human umbilical vein endothelial cells. J Biol Chem 277: 46248-46255, 2002.

7. Nam JO, Kim JE, Jeong HW, Lee SJ, Lee BH, Choi JY, Park RW, Park JY and Kim IS: Identification of the $\alpha v \beta 3$ integrin-interacting motif of $\beta$ ig-h 3 and its anti-angiogenic effect. J Biol Chem 278: 25902-25909, 2003.

8. Mizejewski GJ: Role of integrins in cancer: survey of expression patterns. Proc Soc Exp Biol Med 222: 124-138, 1999.

9. Minamiguchi K, Kumagai H, Masuda T, Kawada M, Ishizuka M and Takeuchi T: Thiolutin, an inhibitor of HUVEC adhesion to vitronectin, reduces paxillin in HUVECs and suppresses tumour cell-induced angiogenesis. Int J Cancer 93: 307-316, 2001.

10. Nikos E,Tsopanoglou NE, Andriopoulou P and Maragoudakis ME: On the mechanism of thrombin-induced angiogenesis: involvement of $\alpha v \beta 3$-integrin. Am J Physiol Cell Physiol 283: 1501-1510, 2002.
11. Burns GF, Cosgrove L, Triglia T, Beall JA, Lopez AF, Werkmeister JA, Begley CG, Haddad AP, d'Apice AJ, Vadas MA, et al: The IIb-IIIa glycoprotein complex that mediates platelet aggregation is directly implicated in leukocyte adhesion. Cell 45: 269-280, 1986.

12. Timar J, Trikha M, Szekeres K, Bazaz R, Tovari J, Silletti S, Raz A and Honn KV: Autocrine motility factor signals integrinmediated metastatic melanoma cell adhesion and invasion. Cancer Res 56: 1902-1908, 1996.

13. Oleksowicz L, Mrowiec Z, Schwartz E, Khorshidi M, Dutcher J and Puszkin E: Characterization of tumour-induced platelet aggregation: the role of immunorelated GPIb and GPIIb/IIIa expression by MCF-7 breast cancer cells. Thromb Res 79: 261-274, 1995.

14. Sheu JR, Lin CH, Peng HC and Huang TF: Triflavin, an Arg-GlyAsp-containing peptide, inhibits human cervical carcinoma (HeLa) cell-substratum adhesion through an RGD-dependent mechanism. Peptides 15: 1391-1398, 1994.

15. Yun Z, Menter DG and Nicolson GL: Involvement of integrin alphavbeta3 in cell adhesion, motility, and liver metastasis of murine RAW117 large cell lymphoma. Cancer Res 56: 3103-3111, 1996.

16. Cohen SA, Trikha M and Mascelli MA: Potential future clinical applications for the GPIIb/IIIa antagonist, abciximab in thrombosis, vascular and oncological indications. Pathol Oncol Res 6: 163-174, 2000.

17. Auzzas L, Zanardi F, Battistini L, Burreddu P, Carta P, Rassu G, Curti $\mathrm{C}$ and Casiraghi G: Targeting alphavbeta3 integrin: design and applications of mono- and multifunctional RGD-based peptides and semipeptides. Curr Med Chem 17: 1255-1299, 2010.

18. Skehan P, Storeng R, Sudiero D, Monks A, McMahon J, Vistica D, Warren JT, Bokesch H, Kenney S and Boyd MR: New colorimetric cytotoxicity assay for anticancer-drug screening. J Natl Cancer Inst 82: 1107-1112, 1990.

19. Chang YS, Chen YQ, Timar J, Nelson KK, Grossi IM, Fitzgerald LA, Diglio CA and Honn KV: Increased expression of alpha IIb beta 3 integrin in subpopulations of murine melanoma cells with high lung-colonizing ability. Int J Cancer 51: 445-451, 1992.

20. Van Belle PA, Elenitsas R, Satyamoorthy K, Wolfe JT, Guerry DI, Schuchter L, Van Belle TJ, Albelda S, Tahin P, Herlyn M and Elder DE: Progression-related expression of beta3 integrin in melanomas and nevi. Hum Pathol 33: 562-567, 1999.

21. Perdih A and Dolenc MS: Small molecule antagonists of integrin receptors. Curr Med Chem 17: 2371-2392, 2010.

22. Brooks PC, Stromblad S, Klemke R, Visscher D, Sarkar FH and Cheresh DA: Antiintegrin alpha v beta 3 blocks human breast cancer growth and angiogenesis in human skin. J Clin Invest 96: 1815-1822, 1995.

23. Mitjans F, Meyer T, Fittschen C, Goodman S, Jonczyk A, Marshall JF, Reyes G and Piulats J: In vivo therapy of malignant melanoma by means of antagonists of $\alpha \mathrm{v}$ integrins. Int J Cancer 87: 716-723, 2000 .

24. Isoai A, Ueno Y, Giga-Hama Y, Goto H and Kumagai HA: A novel Arg-Gly-Asp containing peptide specific for platelet aggregation and its effect on tumor metastasis: a possible mechanism of RGD peptide-mediated inhibition of tumor metastasis. Cancer Lett 65: 259-264, 1992.

25. Buerkle MA, Pahernik SA, Sutter A, Jonczyk AKM and Dellian M: Inhibition of the alpha-nu integrins with a cyclic RGD peptide impairs angiogenesis, growth and metastasis of solid tumours in vivo. Br J Cancer 86: 788-795, 2002.

26. Perkins JJ, Duong LT, Fernandez-Metzler C, Hartman GD, Kimmel DB, Leu C-T, Lynch JJ, Prueksaritanont T, Rodan GA, Rodan SB, et al: Non-peptide alpha(v)beta(3) antagonists: identification of potent, chain-shortened RGD mimetics that incorporate a central pyrrolidinone constraint. Bioorg Med Chem Lett 13: 4285-4288, 2003.

27. Han HD, Mangala LS, Lee JW, Shahzad MM, Kim HS, Shen D, Nam EJ, Mora EM, Stone RL, Lu C, et al: Targeted gene silencing using RGD-labeled chitosan nanoparticles. Clin Cancer Res 16: 3910-3922, 2010.

28. Roman J, Ritzenthaler JD, Roser-Page S, Sunx and Han S: Alpha5beta1-integrin expression is essential for tumor progression in experimental lung cancer. Am J Respir Cell Mol Biol 43: 684-691, 2010.

29. Fire A, Xu S, Montgomery MK, Kostas SA, Driver SE and Mello CC: Potent and specific genetic interference by doublestranded RNA in Caenorhabditis elegans. Nature 391: 806-811, 1998. 
30. Castanotto D and Rossi JJ: The promises and pitfalls of RNA-interference-based therapeutics. Nature 457: 426-433, 2009.

31. Hart IR, Birch M and Marshall JF: Cell adhesion receptor expression during melanoma progression and metastasis. Cancer Metastasis Rev 10: 115-128, 1991.

32. Seftor RE: Role of the beta3 integrin subunit in human primary melanoma progression: multifunctional activities associated with alpha(v)beta3 integrin expression. Am J Pathol 153: 1347-1351, 1998.

33. Switala-Jelen K, Dabrowska K, Opolski A, Lipinska L, Nowaczyk M and Gorski A: The biological functions of beta3 integrins. Folia Biol 50: 143-152, 2004.

34. Akiyama SK, Olden K and Yamada KM: Fibronectin and integrins in invasion and metastsis. Cancer Metastasis Rev 14: 173-189, 1995.

35. Palumbo JS, Kombrinck KW, Drew AF, Grimes TS, Kiser JH, Degen JL and Bugge TH: Fibrinogen is an important determinan of the metastatic potential of circulating tumor cells. Blood 96 : 3302-3309, 2000.

36. Yi M and Ruoslahti E: A fibronectin fragment inhibits tumor growth, angiogenesis and metastasis. Proc Natl Acad Sci USA 98: 620-624, 2001 .

37. Gong W, Liu Y, Huang B, Lei Z, Wu F-H, Li D, Feng Z-H and Zhang G-M: Recombinant CBD-HepII polypeptide of fibronectin inhibits $\alpha v \beta 3$ signaling and hematogenous metastasis of tumor. Biochem Biophys Res Commun 367: 144-149, 2008.

38. Ramos OH, Kauskot A, Cominetti MR, Bechyne I, Salla Pontes CL Chareyre F, Manent J, Vassy R, Giovannini M, Legrand C, et al: A novel avb3-blocking disintegrin containing the RGD motive DisBa-01, inhibits bFGF-induced angiogenesis and melanoma metastasis. Clin Exp Metastasis 25: 53-64, 2008.

39. Sheldrake HM and Patterson LH: Function and antagonism of beta3 integrins in the development of cancer therapy. Curr Cancer Drug Targets 9: 519-540, 2009.

40. Gehlsen KR, Davis GE and Sriramarao P: Integrin expression in human melanoma cells with differing invasive and metastatic properties. Clin Exp Metastasis 10: 111-120, 1992

41. Rebhun RB, Cheng H, Gershenwald JE, Fan D, Fidler IJ and Langley RR: Constitutive expression of the alpha4 integrin correlates with tumorigenicity and lymph node metastasis of the B16 murine melanoma. Neoplasia 12: 173-182, 2010.
42. Zheng S, Shen J, Jiao Y, Zhang C, Wei M, Hao S and Zeng X: Platelets and fibrinogen facilitate each other in protecting tumor cells from natural killer cytotoxicity. Cancer Sci 100: 859-865, 2009.

43. Cavanaugh PG, Sloane BF and Honn KV: Role of the coagulation system in tumor-cell-induced platelet aggregation and metastasis. Haemostasis 18: 37-46, 1988.

44. Crissman JD, Hatfield JS, Menter DG, Sloane B and Honn KV: Morphological study of the interaction of intravascular tumor cells with endothelial cells and subendothelial matrix. Cancer Res 48: 4065-4072, 1988

45. Liu Y, Zhao F, Gu W, Yang H, Meng Q, Zhang Y, Yang $H$ and Duan Q: The roles of platelet GPIIb/IIIa and alphavbeta3 integrins during HeLa cells adhesion, migration, and invasion to monolayer endothelium under static and dynamic shear flow. J Biomed Biotechnol 2009: 829243, 2009.

46. Ria R, Vacca A, Ribatti D, Di Raimondo F, Merchionne F and Dammacco F: Alpha(v)beta(3) integrin engagement enhances cell invasiveness in human multiple myeloma. Haematologica 87: 836-845, 2002.

47. Sato T, Sakai T, Noguchi Y, Takita M, Hirakawa S and Ito A: Tumor-stromal cell contact promotes invasion of human uterine cervical carcinoma cells by augmenting the expression and activation of stromal matrix metalloproteinases. Gynecol Oncol 92: 47-56, 2004.

48. Cary LA and Guan JL: Focal adhesion kinase in integrinmediated signaling. Front Biosci 4: D102-D113, 1999.

49. Hao H, Naomoto Y, Bao X, Watanabe N, Sakurama K, Noma K, Motoki T, Tomono Y, Fukazawa T, Shirakawa Y, et al: Focal adhesion kinase as potential target for cancer therapy (Review). Oncol Rep 22: 973-979, 2009.

50. Yang J, Price MA, Li GY, Bar-Eli M, Salgia R, Jagedeeswaran R, Carlson JH, Ferrone S, Turley EA and McCarthy JB: Melanoma proteoglycan modifies gene expression to stimulate tumor cell motility, growth, and epithelial-to-mesenchymal transition. Cancer Res 69: 7538-7547, 2009.

51. Hou CH, Yang RS, Hou SM and Tang CH: TNF- $\alpha$ increases $\alpha v \beta 3$ integrin expression and migration in human chondrosarcoma cells. J Cell Physiol 226: 792-799, 2011. 